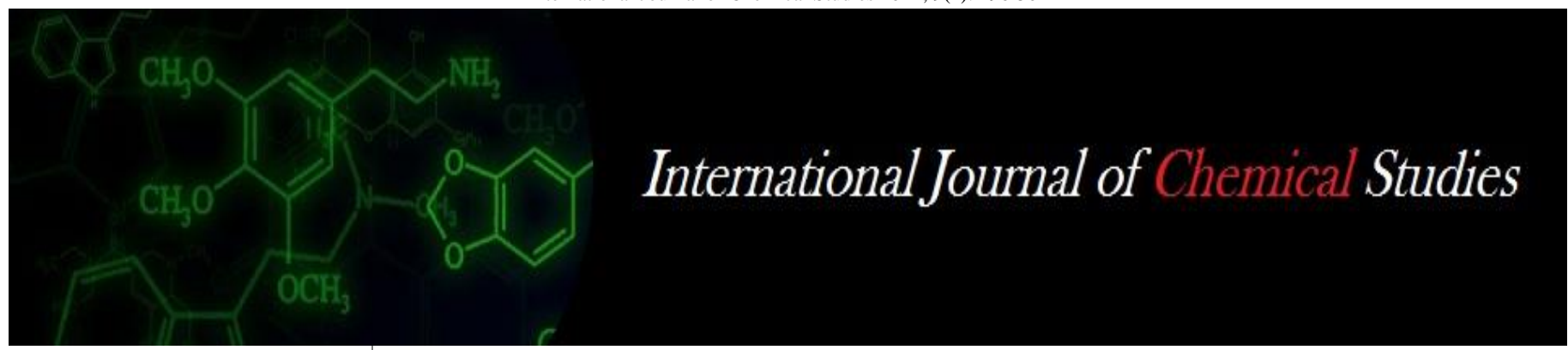

P-ISSN: 2349-8528

E-ISSN: 2321-4902

www.chemijournal.com

IJCS 2021; 9(1): 496-502

(C) 2021 IJCS

Received: 18-11-2020

Accepted: 27-12-2020

Komali Joseph G

Department of Horticulture,

UAS, Raichur, Karnataka, India

Jaiprakash Narayan RP

Department of Horticulture,

UAS, Raichur, Karnataka, India

Kapil Patil

Department of Horticulture,

UAS, Raichur, Karnataka, India

Corresponding Author:

Komali Joseph G

Department of Horticulture,

UAS, Raichur, Karnataka, India

\section{Studies on genetic variability and divergence in onion (Allium cepa L.)}

\author{
Komali Joseph G, Jaiprakash Narayan RP and Kapil Patil
}

DOI: https://doi.org/10.22271/chemi.2021.v9.i1g.11280

\begin{abstract}
A study on variability, heritability, genetic advance and genetic divergence between traits in fifty three diverse onion genotypes was carried out for bulb yield, yield attributing traits and quality parameters. The range of variation was maximum for average bulb weight followed by leaf area, total soluble solids and yield per plot. The genotypic coefficient of variation (GCV) was high for average bulb weight $(16.09 \%)$ followed by yield per plot $(13.06 \%)$, total soluble solids $(11.94 \%)$, leaf area $(11.75 \%)$ and leaf area index $(11.75 \%)$. The phenotypic coefficient of variation (PCV) was high for average bulb weight $(16.90 \%)$ followed by leaf area $(16.41 \%)$, leaf area index $(16.41 \%)$, yield per plot $(13.70 \%)$ and total soluble solids $(12.77 \%)$. Higher heritability estimates along with high genetic advance as per cent of mean (GAM) was observed for yield per plot followed by average bulb weight and total soluble solids. All fifty three genotypes were grouped into ten different clusters. The highest inter cluster distance was observed between cluster IV and X (204.78) and lowest between cluster I and V (35.56).Based on cluster means the important cluster was cluster IX for plant height, bulb neck thickness, number of rings cluster $\mathrm{X}$ for leaf area, leaf area index, average bulb weight, total soluble solids, bulb length and yield per plot cluster VIII for number of leaves cluster V for bulb diameter and cluster VII for bulb shape index. Accordingly, parents could be selected for hybridization. The highest intra cluster distance was observed between cluster VII (40.09). The high diversity found in the genotypes showed its great potential for improving qualitative as well as quantitative traits in onion.
\end{abstract}

Keywords: Allium cepa L., genetic variability, heritability, genetic divergence

\section{Introduction}

Onion (Allium cepa L.) is one of the most important bulbous vegetable crops grown all over the world (Best, 2000) ${ }^{[3]}$. It belongs to the family Liliaceae. It is consumed as a vegetable and condiment. The green leaves, immature and mature bulbs are eaten raw or used in vegetable preparations. Onion has many medicinal values and used for preparation of various Homeopathic, Unani and Ayurvedic medicines. It promotes appetite, useful against malaria, night blindness and lowers blood pressure. Onion has strong flavour due to presence of sulphur containing compound in very small quantity (about $0.005 \%$ ) in the form of volatile oil allyl propyl disulphide $\left(\mathrm{C}_{6} \mathrm{H}_{12} \mathrm{O}_{2}\right)$ responsible for distinctive smell and pungency and acts as gastric, stimulant and promotes digestion. The quality of onion depends on shape, size, colour and pungency of bulbs. A logical way to start any breeding programme is to estimate the variation in the available materials. It is said that presence of genetic variability is the "sine quanon" of any such programme. To improve the yield through selection, information on the nature and magnitude of variability present in a population is an important pre-requisite for starting any breeding programme. The ultimate goal of breeding programme is to increase the yield potential of a popular crop coupled with resistance to disease and pests which are being effectively used for determining the rate of various yield components in different crops leading to the selection of superior genotypes. The breeder's choice of the material for any improvement work consequently depends on the amount of genetic variability present.

Generally diverse plants are expected to give high hybrid vigour and hence, it necessitates the study of genetic divergence among the existing varieties and germplasm collection for identification of more heterotic parents for hybridization programme. The information on genetic divergence of various traits particularly of those that contribute to yield and quality would be most useful in planning the breeding programme. Before taking up crop improvement programme in any crop species a thorough knowledge regarding the amount of 
genetic divergence existing in that particular crop for various characters is essential. Considering above facts the present investigation is an attempt to assess the magnitude of genetic variability and diversity in bulb yield potential of onion genotypes with objectives like to find out the extent of genetic variability for yield and yield contributing characters and to identify the genetic divergence for growth, yield and quality parameters.

\section{Materials and Methods}

The experiment was carried out during 2017-2018, at the Main Agricultural Research Station, College of Agriculture, University of Agricultural Sciences, Raichur, Karnataka on fifty three genotypes of onion. Fifty three genotypes (Table 1) were taken for the study. Seedlings of 50 days old were transplanted in main field during late kharif season. The experiment was laid out by adopting Randomised Complete Block Design with two replications with a spacing of $15 \mathrm{~cm} \times$ $10 \mathrm{~cm}$. Hundred plants per genotype per replication were maintained. The collected data was analysed as per the method suggested by Burton and De Vane (1953) ${ }^{[5]}$, Hanson et al. (1956) ${ }^{[9]}$ and Johnson et al. (1955) ${ }^{[12]}$. The observations were recorded on ten randomly selected plants from each plot for 12 characters namely plant height $(\mathrm{cm})$, no. of leaves, leaf area $\left(\mathrm{cm}^{2}\right)$, leaf area index, yield per plot $(\mathrm{Kg})$, average weight of the bulb $(\mathrm{g})$, diameter of bulb $(\mathrm{cm})$, bulb length (cm), number of rings per bulb, total soluble solids (TSS), bulb neck thickness and bulb shape index. Plot means over the replications were used for the statistical analysis. This statistical data analysis was carried out by using indostat software. The total soluble solids (TSS) were determined with digital refractometer calibrated using distilled water. Results were reported as ${ }^{\circ}$ Brix at $22{ }^{\circ} \mathrm{C}$ (Ruck, 1963).Genetic diversity was studied using Mahalanobis (1936) [7, 14] generalized distance $\left(\mathrm{D}^{2}\right)$ extended by Rao (1952) ${ }^{[17]}$. Clustering of genotypes was done according to Tocher' smethod (Rao, 1952) ${ }^{[17]}$. Average intra-cluster distance was calculated by the following formula as suggested by Singh and Choudhary (1985) ${ }^{[19]}$.

Table 1: List of genotypes (Treatments)

\begin{tabular}{|c|c|c|}
\hline AVT -226 & AVT -250 & OC $18-21$ \\
\hline AVT -224 & AVT -221 & OA $18-08$ \\
\hline AVT -248 & AVT -223 & OC $18-30$ \\
\hline AVT -243 & AVT -232 & OB $18-07$ \\
\hline AVT -245 & AVT -241 & OC $18-32$ \\
\hline AVT -228 & AVT -116 & OC $18-35$ \\
\hline AVT -213 & AVT -106 & OC $18-17$ \\
\hline AVT -103 & IET- 18 & OA $18-12$ \\
\hline IET -02 & AVT -107 & OB $18-09$ \\
\hline IET -10 & IET -08 & OB $18-06$ \\
\hline Pusa Madhavi & Bhima Dark Red & OC $18-26$ \\
\hline Bellary Red & Pamankallur Local & OC $18-41$ \\
\hline Bhima Swetha & PusaRidhi & OC $18-48$ \\
\hline ArkaPragathi & Arka Niketan & OC $18-50$ \\
\hline Bhima Safed & OC $18-23$ & OC $18-24$ \\
\hline OC $18-45$ & OA $18-10$ & OC $18-01$ \\
\hline OA $18-14$ & OA $18-18$ & OC $18-43$ \\
\hline OC $18-28$ & OB $18-03$ & \\
\hline
\end{tabular}

\section{Results and Discussion}

The analysis of variance revealed significant difference among the genotypes for each character, indicating the existence of variability among the genotypes for the character studied. Estimates of phenotypic (PCV) and genotypic (GCV) coefficient of variation, broad sense heritability $\left(h^{2}\right)$, genetic advance under selection in absolute units (GS) and genetic advance expressed as a percentage of grand mean (GAM) for the studied traits are presented in Table 2. The genotypic coefficient of variation (GCV) was less than that of phenotypic coefficient of variation (PCV) for all characters (Table 2), indicating the effect of environment on their genetic expression.

Table 2: Estimation of variability, heritability and genetic advance as percent of mean for different characters in onion genotypes

\begin{tabular}{|c|c|c|c|c|c|c|c|}
\hline Characters & Range & Mean & GCV & PCV & GA & GAM & $\mathbf{h}^{2}$ \\
\hline Plant height & $53.40-75.60$ & 64.50 & 7.10 & 7.97 & 8.8038 & 13.01 & 79.18 \\
\hline Number of leaves per plant & $11.87-17.10$ & 14.48 & 6.06 & 11.24 & 0.9532 & 6.72 & 29.02 \\
\hline Leaf area & $808.90-1535.28$ & 1172.09 & 11.75 & 16.41 & 209.0570 & 17.32 & 51.23 \\
\hline Leaf area index & $5.39-10.24$ & 7.81 & 11.75 & 16.41 & 1.3954 & 17.34 & 51.28 \\
\hline Yield per plot & $5.60-10.35$ & 7.97 & 13.06 & 13.70 & 2.0743 & 25.65 & 90.90 \\
\hline Average bulb weight & $67.40-144.50$ & 105.95 & 16.09 & 16.90 & 30.5257 & 31.57 & 90.72 \\
\hline Bulb diameter & $4.30-6.61$ & 5.45 & 9.73 & 10.26 & 0.9969 & 19.02 & 90.00 \\
\hline Bulb length & $4.28-5.98$ & 5.13 & 6.20 & 7.30 & 0.5514 & 10.83 & 72.02 \\
\hline Number of rings per bulb & $11.60-16.10$ & 13.85 & 5.87 & 9.42 & 1.0058 & 7.55 & 38.93 \\
\hline Total soluble solids & $8.57-15.29$ & 11.93 & 11.94 & 12.77 & 2.87 & 23.01 & 87.50 \\
\hline Bulb neck thickness & $0.78-1.38$ & 1.08 & 9.65 & 11.95 & 0.1619 & 16.06 & 65.22 \\
\hline Bulb shape index & $0.82-1.16$ & 0.99 & 6.16 & 10.74 & 0.0713 & 7.30 & 32.96 \\
\hline
\end{tabular}

GCV - Genotypic coefficient of variation, GA - Genetic advancement, h2 - Broad sense heritability, PCV - Phenotypic coefficient of variation

GAM - Genetic advancement as percent of mean

\section{Genotypic coefficient of variance}

It is revealed from the table 2that genotypic coefficient of variation varied from $5.87 \%$ (number of rings) to $16.09 \%$ (average bulb weight). The moderate per cent of GCV was associated with the character viz., average bulb weight $(16.09 \%)$ followed by yield per plot $(13.06 \%)$, total soluble solids (11.94\%), leaf area (11.75\%) and leaf area index $(11.75 \%)$. The above all parameters which expressed more than 10.1 per cent and less than 20.1 per cent GCV might be categorised as characters with moderate GCV.

Bulb diameter (9.73\%), bulb neck thickness (9.65\%), plant height $(7.10 \%)$, bulb length $(6.20 \%)$, bulb shape index $(6.16 \%)$, number of leaves $(6.06 \%)$ and number of rings $(5.87 \%)$ all these parameters which expressed less than 10.1 per cent GCV categorised as characters with low GCV. The parameters which expressed more than 20.1 per cent GCV might be categorised as characters with high GCV. In the present study no such parameters are recorded. The findings are in close harmony with the results of Haydar et al. (2007) ${ }^{[10]}$, Dhotre (2009) ${ }^{[6]}$, Hosamani et al. (2010) [11], Singh and Dubey (2011) ${ }^{[19]}$, Ram et al. (2011) ${ }^{[4,16]}$, Nenad et al. (2013) ${ }^{[15]}$ and Ananthan and Balkrishnamoorthy (2007) ${ }^{[1]}$. 


\section{Phenotypic coefficient of variance}

The characters which exhibited more than 20.1 per cent of PCV were considered as the characters with high PCV in the present study no such parameter was recorded. Average bulb weight $(16.90 \%)$, leaf area index $(16.41 \%)$ and leaf area $(16.41 \%)$, yield per plot $(13.70 \%)$, total soluble solids $(12.77 \%)$, bulb neck thickness $(11.95 \%)$, number of leaves (11.24\%), Bulb shape index $(10.74 \%)$ and bulb diameter $(10.26 \%)$ were the characters with moderate per cent of PCV. Characters which exhibited PCV\% between 10.1 to 20 per cent were categorised as moderate characters. Number of rings $(9.42 \%)$, plant height $(7.97 \%)$ and Bulb length $(7.30 \%)$, were categorised as low PCV characters. Characters which exhibited PCV\% less than $10.1 \%$ is considered as the low PCV characters. The findings are in close harmony with the results of Mohanty (2001a), Dhotre (2009) [6], Hosamani et al. (2010) [11], Singh and Dubey (2011) ${ }^{[19]}$ and Haydar et al. (2007) $^{[10]}$.

Among the characters studied, plant height, yield per plot, average bulb weight, bulb diameter and total soluble solids shows less difference between genotypic and phenotypic coefficient variance, this indicates that little influence of environment on the expression of these characters. In other words, improvement can be achieved by simple selection based on phenotypic performance. Whereas moderate difference between GCV and PCV was observed for bulb length, number of rings, bulb neck thickness. However, high difference between GCV and PCV was observed for number of leaves, leaf area, leaf area index, bulb shape index indicating environmental factors has moderate influence on these characters.

\section{$\mathbf{h}^{2}$ (Heritability)}

High heritability (more than $60.1 \%$ ) was associated with the characters like yield per plot $(90.90 \%)$ followed average bulb weight $(90.72 \%)$, bulb diameter $(90.00 \%)$, total soluble solids $(87.50 \%)$, plant height $(79.18 \%)$, bulb length $(72.02 \%)$ and bulb neck thickness (65.22\%). Leaf area index (51.28\%), leaf area $(51.23 \%)$, number of rings $(38.93 \%)$ and bulb shape index $(32.96 \%)$ were considered as moderate heritability. (30.1 to $60 \%)$. Number of leaves $(26.78 \%)$ were categorised as low heritable characters. (Less than 30\%). These findings are in conformity with those of Dhotre (2009) ${ }^{[6]}$, Hosamani et al. (2010) ${ }^{[11]}$, Ram et al. (2011) ${ }^{[4,16]}$, Bharti et al. $(2011)^{[4,16]}$, Haydar et al. (2007) [10], Yaso (2007) ${ }^{[22]}$ and Golani et al. (2006) ${ }^{[8]}$.

Heritability value indicates the heritable properties of variation. Heritability provides the information about the amount of transmissible genetic variation to the total variation happen to be the most important factors, which determine genetic improvement or response to selection. The estimate of genetic advance as per cent of mean provides more reliable information regarding the effectiveness of selection in improving a trait. However, heritability gives only a rough estimate and alone it is not sufficient to determine the amount of variation which is heritable. Hence heritable variation can be realized with greater accuracy when heritability along with genetic advance is studied which indicates additive gene effects.

\section{Genetic advance as percent of mean (GAM)}

The characters with more than 20.1 per cent GAM categorised as high GAM. Average bulb weight $(31.57 \%)$ followed by yield per plot $(25.65 \%)$ and total soluble solids $(23.01 \%)$ were the traits with high GAM. Bulb diameter (19.02\%), leaf area index $(17.34 \%)$, leaf area $(17.32 \%)$, bulb neck thickness $(16.06 \%)$, plant height $(13.01 \%)$ and bulb length $(10.83 \%)$ were the characters with moderate GAM. The characters with 10.1 to 20 per cent GAM were considered as moderate GAM. Number of rings $(7.55 \%)$, bulb shape index $(7.30 \%)$ and number of leaves $(6.72 \%)$ were characters which had low GAM. These were the characters which had less than 10 per cent GAM. These findings are in conformity with those of Golani et al. (2006) [8], Ananthan and Balkrishnamoorthy (2007) ${ }^{[1]}$ and Dhotre (2009) ${ }^{[6]}$.

High genetic advance as per cent of mean was observed for average bulb weight, yield per plot and total soluble solids indicates that these characters are governed by additive genes and selection will be rewarding for improvement of such traits. Moderate and low GAM of these characters indicates that the characters are governed by non-additive genes. Genetic advance is the measure of improvement that can be achieved by practicing selection in population. The coefficient of variation detects the extent of variability present for different characters and it does not indicate the heritable portion. To obtain the magnitude of the heritable portion of variability, it is essential to know the heritability estimates for different characters. High estimates of heritability coupled with high genetic advance was observed in characters like average bulb weight, yield per plot and total soluble solids. These characters are under additive gene effect and could be improved by simple selection schemes. The heritability being exhibited due to favourable influence of environment rather than genotype and selection for such trait may not be rewarding.

High estimates of heritability coupled with moderate GAM was observed in characters bulb diameter, plant height, bulb length and bulb neck thickness. Moderate heritability coupled with moderate GAM was observed in characters leaf area and leaf area index. Moderate heritability coupled with low GAM was observed in characters number of rings and bulb shape index indicating that the characters are highly influenced by environment effects and selection would be ineffective. Low heritability coupled with low GAM was observed in character number of leaves. Heritability estimates in the broad sense include both additive and non-additive gene effects and in the narrow sense include only additive gene effects. Since, heritability estimates fluctuate in interaction with environment as well as genetic background, it should be studied only along with genetic advance for characters in concern for effective selection.

\section{Genetic divergence}

Based on $\mathrm{D}^{2}$ value estimates of genetic divergence the fifty three onion accessions were grouped into ten distinct clusters. A wide range of diversity was observed in the experimental material for the majority of the characters studied. The relative contribution of different characters for genetic divergence $\left(\mathrm{D}^{2}\right)$ is given in the Table3. Bulb diameter $(25.47 \%)$ contributed maximum to the total genetic diversity among the genotypes followed by total soluble solids $(21.84 \%)$, average bulb weight $(19.09 \%)$, yield per plot $(10.09 \%)$, plant height $(9.36 \%)$, bulb length $(7.47 \%)$, bulb neck thickness $(2.76 \%)$, number of rings per bulb $(2.03 \%)$ and leaf area $(1.6 \%)$. While there was little and negligible contribution from number of leaves $(0.29 \%)$.Similar results were observed by Sunil et al. (2014) ${ }^{[21]}$ and Fahima et al. (2019) ${ }^{\text {[7] }}$. The distribution pattern of entries into various clusters is given in Table4. Cluster I and cluster II were the largest having 17 genotypes each followed by cluster III with 6 genotypes, cluster VII with 4 genotypes, cluster IV with 3 genotypes and cluster VIII with 2 genotypes. Whereas, clusters V, VI, IX and X are solitary. 
Table 3: Percent contribution of different characters to the total divergence in onion genotypes

\begin{tabular}{|c|c|c|c|}
\hline Sl. No. & Source & Times ranked 1 & Contribution \% \\
\hline 1. & Plant height at 90 DAT & 129 & 9.36 \\
\hline 2. & Number of leaves per plant at 90 DAT & 4 & 0.29 \\
\hline 3. & Leaf area at 90 DAT & 22 & 1.6 \\
\hline 4. & Average weight of the bulb & 263 & 19.09 \\
\hline 5. & Yield per plot & 139 & 10.09 \\
\hline 6. & Total soluble solids & 301 & 21.84 \\
\hline 7. & Bulb length & 103 & 7.47 \\
\hline 8. & Bulb neck thickness & 38 & 2.76 \\
\hline 9. & Diameter of the bulb & 351 & 25.47 \\
\hline 10. & Number of rings per bulb & 28 & 2.03 \\
\hline
\end{tabular}

DAT - Days after transplanting

Table 4: Cluster composition based on $\mathrm{D}^{2}$ statistic in onion

\begin{tabular}{|c|c|c|}
\hline Clusters & Number of genotypes & Genotypes included in the cluster \\
\hline I & 17 & $\begin{array}{c}\text { OA 18-14, OC 18-41, OC 18-28, OA 18-18, OC 18-23, OA 18-08, OA 18-10, OC 18-30, OC 18-26, Bhima } \\
\text { Safed, OC 18-45, Arka Niketan, OB 18-06, Arka Pragathi, Pusa Ridhi, Pusa Madhavi and Pamankallur Local. }\end{array}$ \\
\hline II & 17 & $\begin{array}{c}\text { OB 18-07, Bhima Swetha, AVT 2-26, AVT 1-16, AVT 2-41, AVT 2-45, AVT 1-07, AVT 2-21, IET - 08, IET - } \\
\text { 02, AVT 2-24, IET - 10, AVT 2-48, IET - 18, OC 18-35, AVT 2-43 and OC 18-21. }\end{array}$ \\
\hline III & 6 & OC 18- 32, OC 18-01, OB 18-09, OC 18-17, OC 18-43 and OC 18-50. \\
\hline IV & 3 & AVT 1-03, OA 18-12 and Bellary Red \\
\hline V & 1 & AVT 2-28 \\
\hline VI & 1 & OC 18-24 \\
\hline VII & 4 & AVT 1-13, AVT 2-50, AVT 2-23 and AVT 2-32. \\
\hline VIII & 2 & AVT 1-06 and OB 18-03 \\
\hline IX & 1 & Bhima Dark Red \\
\hline X & 1 & OC 18-48 \\
\hline
\end{tabular}

Intra-cluster average $\mathrm{D}^{2}$ values are presented in Table5. Among ten clusters, cluster VII with four genotypes showed maximum intra-cluster diversity $\left(\mathrm{D}^{2}=40.09\right)$ followed by cluster III with six genotypes having intra-cluster diversity $\left(\mathrm{D}^{2}=36.90\right)$ cluster IV with three genotypes having intracluster diversity $\left(\mathrm{D}^{2}=28.99\right)$, cluster II with 17 genotypes having intra-cluster diversity $\left(\mathrm{D}^{2}=28.08\right)$, cluster 1 with 17 genotypes having intra-cluster diversity $\left(D^{2}=23.30\right)$ and cluster VIII with two genotypes having intra-cluster diversity $\left(D^{2}=14.77\right)$. Selection with this cluster might be exercised on the highest mean for the desirable traits. The clusters V, VI, IX and $X$ had no intra-cluster distance $\left(D^{2}=0.000\right)$ as that possess single genotype. These findings are in conformity with those of Fahima et al. (2019) ${ }^{[7]}$ and Ashwini et al. $(2018)^{[2]}$.

Table 5: Intra and inter-cluster $\mathrm{D}^{2}$ values in onion genotypes

\begin{tabular}{|c|c|c|c|c|c|c|c|c|c|c|}
\hline \multicolumn{11}{|c|}{ Cluster distances } \\
\hline Clusters & I & II & III & IV & $\mathbf{V}$ & VI & VII & VIII & IX & $\mathbf{X}$ \\
\hline $\mathrm{I}$ & 23.30 & 46.37 & 56.14 & 79.54 & 35.56 & 52.60 & 85.27 & 68.32 & 78.43 & 70.89 \\
\hline II & & 28.08 & 83.55 & 48.76 & 40.22 & 46.34 & 46.61 & 76.71 & 61.02 & 115.28 \\
\hline III & & & 36.90 & 159.66 & 57.64 & 67.90 & 89.08 & 56.78 & 100.63 & 60.46 \\
\hline IV & & & & 28.99 & 100.91 & 65.69 & 94.17 & 119.32 & 101.55 & 204.78 \\
\hline $\mathrm{V}$ & & & & & 0.00 & 72.79 & 54.23 & 77.30 & 86.62 & 64.41 \\
\hline VI & & & & & & 0.00 & 59.53 & 26.19 & 95.76 & 154.28 \\
\hline VII & & & & & & & 40.09 & 84.70 & 77.86 & 137.28 \\
\hline VIII & & & & & & & & 14.77 & 151.04 & 152.56 \\
\hline IX & & & & & & & & & 0.00 & 81.07 \\
\hline$X$ & & & & & & & & & & 0.00 \\
\hline
\end{tabular}

Diagonal values indicates intra cluster distance and off diagonal indicates inter-cluster distance

Based on the distance between clusters (inter-cluster distances), the maximum divergence was observed between cluster IV and X $\left(D^{2}=204.78\right)$ followed by cluster III and IV $\left(\mathrm{D}^{2}=159.66\right)$, cluster VI and $\mathrm{X}\left(\mathrm{D}^{2}=154.28\right)$, cluster VIII and $X\left(D^{2}=152.56\right)$, cluster VII and $X\left(D^{2}=137.28\right)$, cluster IV and VIII $\left(D^{2}=119.32\right)$, cluster II and $X\left(D^{2}=115.28\right)$, cluster IV and IX $\left(D^{2}=101.55\right)$, cluster IV and V $\left(D^{2}=100.91\right)$, cluster III and IX $\left(D^{2}=100.63\right)$, cluster VI and IX $\left(D^{2}=95.76\right)$, cluster IV and VII $\left(D^{2}=94.17\right)$, cluster III and VII $\left(D^{2}=89.08\right)$ and so on. Selection of parents from such clusters for hybridization programme would help to achieve novel recombinants. The distance between cluster VI and VIII $\left(\mathrm{D}^{2}=26.19\right)$ followed by cluster I and V $\left(D^{2}=35.56\right)$ will be lesser. There is significant genetic variability among tested genotypes that indicates the presence of excellent opportunity to bring about improvement through wide hybridization by crossing genotypes in different clusters. The hybridization between the genotypes falling in the most distant clusters should result in to maximum hybrid vigour and eventually may give rise desirable recombinants. Based on cluster means the important cluster was cluster IX for plant height, bulb neck thickness, number of rings cluster $\mathrm{X}$ for leaf area, leaf area index, average bulb weight, total soluble solids, bulb length and yield per plot cluster VIII for number of leaves cluster V for bulb diameter and cluster VII for bulb shape index. The means of the clusters were presented in the table 6.Crosses among diverse parents are likely to yield desirable combinations. Therefore, a crossing programme should be initiated between the genotypes 
belonging different clusters. The greater the distance between two cluster, the wider the genetic diversity among the parents to be included in hybridization programme. Parents combining high yield potential with wide genetic diversity are likely to yield superior segregants with in short period. The genotypes with high mean value from any cluster can either straight away be used for adoption or can be used in hybridization for yield improvement.

Table 6: The mean values of 12 characters for ten clusters formed by 53 genotypes of onion

\begin{tabular}{|c|c|c|c|c|c|c|c|c|c|c|c|c|}
\hline$@ *$ & $\mathbf{1}$ & $\mathbf{2}$ & $\mathbf{3}$ & $\mathbf{4}$ & $\mathbf{5}$ & $\mathbf{6}$ & $\mathbf{7}$ & $\mathbf{8}$ & $\mathbf{9}$ & $\mathbf{1 0}$ & $\mathbf{1 1}$ & $\mathbf{1 2}$ \\
\hline 1 & 70.96 & 13.63 & 1256.76 & 8.38 & 98.55 & 8.32 & 13.53 & 5.09 & 1.00 & 4.82 & 12.66 & 1.06 \\
\hline 2 & 65.12 & 14.46 & 1181.52 & 7.88 & 88.60 & 7.46 & 12.54 & 5.15 & 1.04 & 5.58 & 13.54 & 0.92 \\
\hline 3 & 69.68 & 13.58 & 1174.52 & 7.83 & 121.22 & 9.57 & 11.03 & 4.73 & 0.91 & 4.92 & 13.47 & 0.97 \\
\hline 4 & 68.28 & 14.64 & 1275.03 & 8.50 & 68.37 & 5.77 & 13.29 & 5.39 & 0.98 & 5.34 & 14.05 & 1.01 \\
\hline 5 & 60.20 & 14.50 & 1122.42 & 7.49 & 100.00 & 8.79 & 13.06 & 4.94 & 1.22 & 5.41 & 13.40 & 0.91 \\
\hline 6 & 69.60 & 13.87 & 900.20 & 6.01 & 89.00 & 7.94 & 10.20 & 5.15 & 0.95 & 5.19 & 13.55 & 0.99 \\
\hline 7 & 58.65 & 15.34 & 1070.84 & 7.14 & 94.15 & 8.43 & 10.78 & 5.17 & 1.05 & 5.97 & 14.43 & 0.87 \\
\hline 8 & 68.95 & 15.41 & 1224.75 & 8.17 & 95.25 & 8.10 & 8.76 & 4.70 & 1.05 & 4.89 & 13.63 & 0.97 \\
\hline 9 & 75.55 & 13.29 & 1386.23 & 9.24 & 111.90 & 8.65 & 13.99 & 5.86 & 0.85 & 6.22 & 12.50 & 0.95 \\
\hline 10 & 72.25 & 14.65 & 1510.59 & 10.07 & 141.90 & 10.15 & 14.05 & 5.25 & 0.93 & 4.99 & 13.10 & 1.07 \\
\hline
\end{tabular}

X1- Plant height, X2-Number of leaves, X3-Leaf area, X4-Leaf area index, X5-Bulb average weight, X6-Total soluble solids, X7-Bulb length,

X8-Bulb neck thickness, X9- Bulb diameter, X10-Number of rings, X11-Bulb shape index, X12-Bulb yield per plot

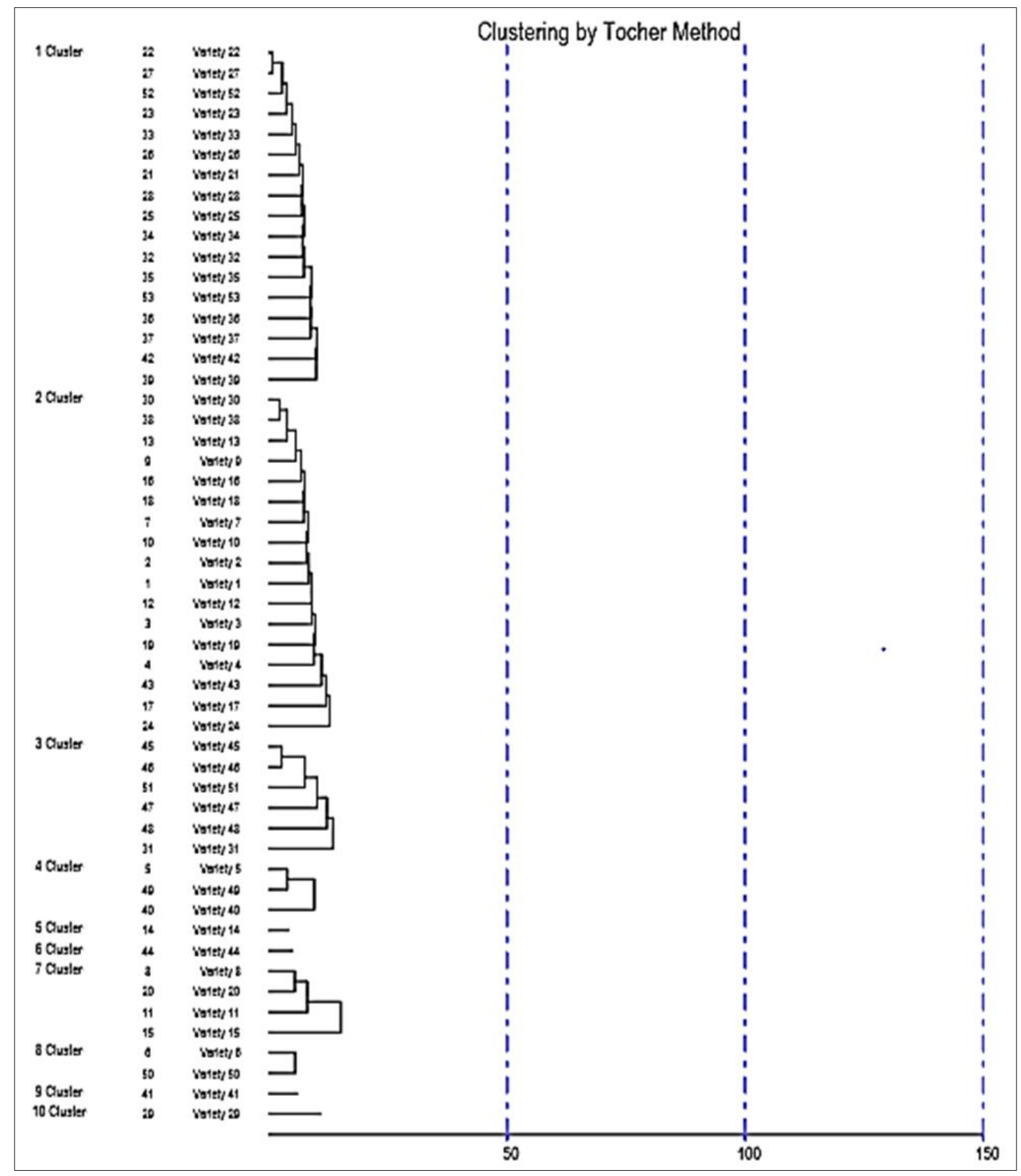

Fig 1: Clustering of genotypes using Tocher method 


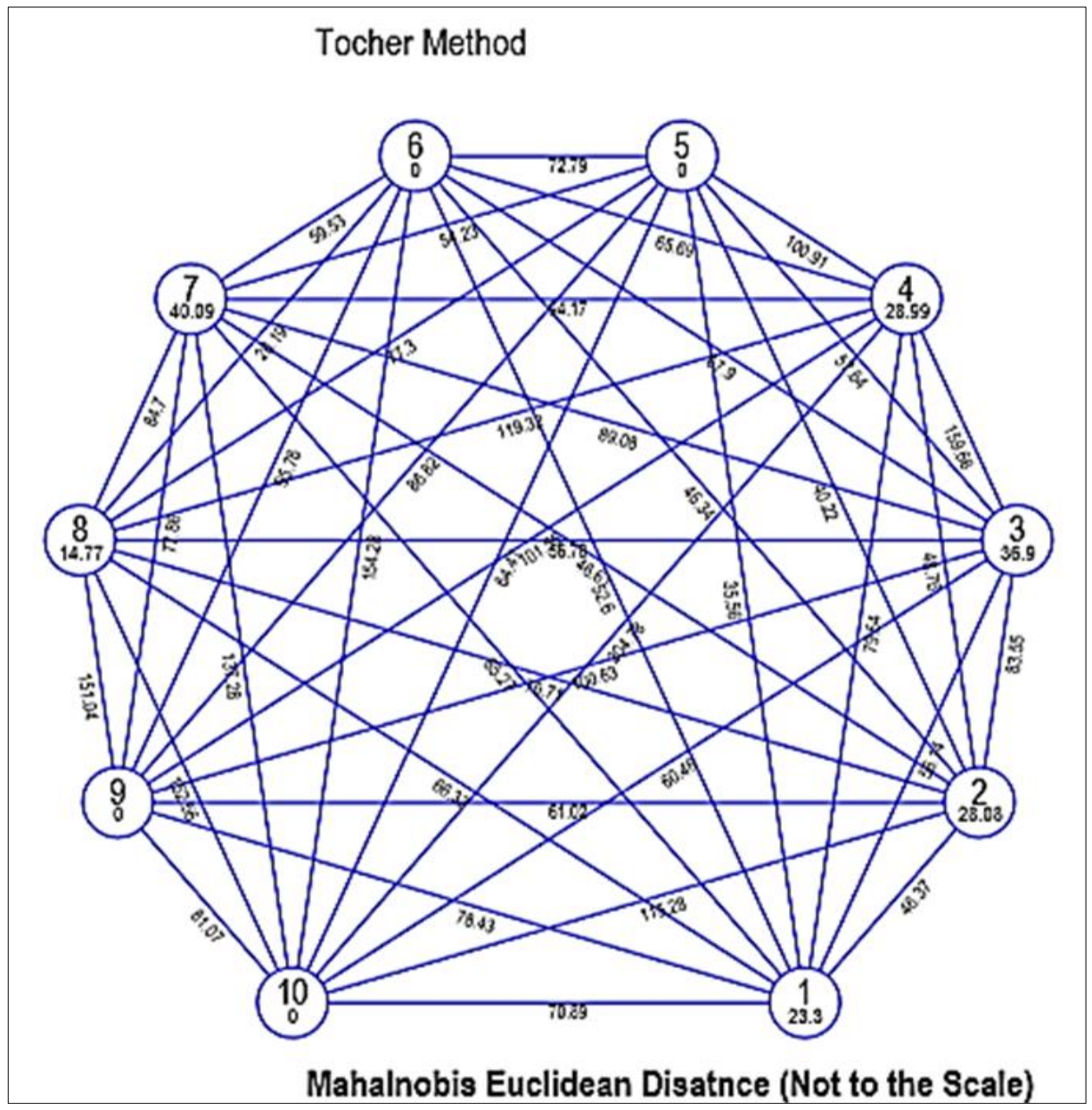

Fig 2: Inter and intra cluster distances between clusters

\section{Conclusion}

It can be concluded that maximum genetic variability in the form of GCV and PCV among studied genotypes was observed for characters like yield per plot, average weight of the bulb and total soluble solids which gives a scope for further improvement. All the characters studied implied to be highly and moderately heritable except number of leaves. Characters like plant height, average weight of the bulb, yield per plot, total soluble solids, bulb length, bulb neck thickness, diameter of bulb, leaf area, leaf area index, number of rings and bulb shape index are highly and moderately heritable. Among the various characters studied during crop growth period, high heritability coupled with high GAM was noticed for average weight of the bulb, total soluble solids and yield per plot which is an indication for direct selection of varieties for these characters.

The highest inter cluster distance exhibited between cluster IV and X followed by between cluster III and IV indicating that the genotypes of these clusters could be used as parents in hybridization programme to obtain a heterotic effect or to segregate broad spectrum of variants as new genotypes from the segregating population.

\section{References}

1. Ananthan M, Balakrishnamoorthy G. Genetic variability and correlation studies in onion (Allium cepavar. cepa) for economic dry matter yield. Agric. Sci. Digest 2007;27(3):190-193.

2. Ashwini PB, Somnath D, Vijay M, Major S. Genetic divergence studies for bulbing and related traits in garlic germplasm during kharif season. Int. J Curr. Microbiol. App. Sci 2018;7(1):2920-2927.
3. Best K. Red onion cultivars trail. Horticultural Nova scotia, kentville agricultural centre, Nova Scotia (Canada) 2000, P10-13.

4. Bharti, Navaldey RB, Ram ML, Meena, Yogita. Genetic variability studies in onion (Allium cepa L.). Annals of Hort 2011;4(2):171-175.

5. Burton GW, De Vane EH. Estimating heritability in talli Feschue (Festuca arundinances) from replicated clones material. Agron J 1953;45:478-481.

6. Dhotre M. Studies on genetic diversity and influence of nitrogen sources on performance of Kharif onion (Allium cepavar. cepa). M.Sc. (Agri.) Thesis, Univ. Agric. Sci., Dharwad 2009.

7. Fahima AF, Paramaguru P, Lakshmanan V, Venkatesan $\mathrm{K}$. Genetic divergence studies in aggregatum onion (Allium cepa L. var. aggregatum Don.) genotypes using Mahalanobis $\mathrm{D}^{2}$ analysis. J Pharmacognosy Phytochem 2019;8(3):463-466.

8. Golani IJ, Vaddoria MA, Mehta DR, Naliyadhara MV, Dobariya KL. Analysis of yield components in onion. Indian J Agric. Res 2006;40(3):224-227.

9. Hanson $\mathrm{CH}$, Robinson HF, Comstock RK. Biometrical studied on yield in segregating population of Korean Lasphadezia. Agron. J 1956;48:314-318.

10. Haydar A, Sharker N, Ahmed MB, Hannan MM, Razvy MA, Hossain M, Hoque A, Karim R. Genetic variability and interrelationship in onion (Allium cepa L.), MiddleEast J Sci. Res 2007;2(3-4):132-134.

11. Hosamani RM, Patil BC, Ajjappalavara PS. Genetic variability and character association studies in onion (Allium cepa L.). Karnataka J Agric. Sci 2010;23(2):302305. 
12. Johnson HW, Robinson HF, Comsock RE. Estimation of genetics and environmental variability in soya bean. Agron. J 1955;47:477-483.

13. Mohanty BK. Genetic variability, interrelationship and path analysis in Kharif onion. Ann Agric. Res 2001a;22(3):349-353.

14. Mahalanobis PC. On the generalized distance in Statistics. Proc. Nation. Academy Sci. (India) 1936;2(9):49-55.

15. Nenad DN, Nandi A, Tripathi P, Sahu A. Genetic variability and correlation in onion. Indian J Agric. Sci 2013;65:793-796.

16. Ram RB, Bharti N, Meena ML, Lata R, Babu M. Genetic variability and correlation studies in onion (Allium cepa L.). An Int. J Pl. Res 2011;24(1):152-156.

17. Rao CR. Advanced Statistical Methods in Biometrical Research. John Wiley and Sons, New York 1952, P357369.

18. Ruck JA. Chemical methods of analysis of fruits and vegetables. Department of Agriculture Canada, Publication No. 11541963.

19. Singh RK, Choudhary BD. Diametrical methods in quantitative genetic analysis. Kalyani publishers, New Delhi 1985, P318.

20. Singh RK, Dubey BK. Studies on genetic divergence in onion advance lines. Indian J Hort 2011;68(1):123-127.

21. Sunil N, Vinod K, Medagam TR, Venkateshwaran K. Phenotypic diversity and genetic variation within a collection of onion (Allium cepa L.) germplasm from peninsular India. Elect. J Pl. Breed 2014;5(4):743-751.

22. Yaso IAA. Phenotypic correlation and path coefficient analysis in some onion genotypes. Egyptian J Plant Breed 2007;11(3):299-306. 